\title{
A Novel Approach to Boost the Seed Cotton Yield via Irradiation to Enhance the Boll Weight and Boll Number in Diploid Cotton
}

\section{Bangaremma Wadeyar* and ST Kajjidoni}

Department of Genetics and Plant Breeding, University of Agricultural Sciences, Dharwad, India

*Corresponding author: Bangaremma Wadeyar, Department of Genetics and Plant Breeding, University of Agricultural Sciences, Dharwad, India, E-mail: bangarammawadeyar@gmail.com

Received date: February 26, 2018; Accepted date: March 29, 2018; Published date: April 05, 2018

Copyright: ( 2018 Wadeyar B, et al. This is an open-access article distributed under the terms of the Creative Commons Attribution License, which permits unrestricted use, distribution, and reproduction in any medium, provided the original author and source are credited.

\begin{abstract}
Diplod cotton especially Gossypium herbeceum are poor seed cotton yielders and also have poor fiber properties while in parallel diploids have good buffering capacity towards the fluctuating environment. Hence an attempt has been made to enhance the yield levels in diploid cotton using gamma rays as an additional variability creating agent. Here a total of one hundred and ten progenies comprising of irradiated $\left(F_{4} M_{4} 45\right)$, unirradiated $\left(F_{4} 52\right)$ and irradiated jayadhar $\left(M_{4} 13\right)$ were evaluated at Main Agricultural Research Station, UAS, Dharwad to obtain information on mean, variance, range, genetic variability, heritability and genetic advanced for thirteen traits. The mean, range and variance among progenies, $\mathrm{F}_{4} \mathrm{M}_{4}$ progenies exhibited relatively higher progeny mean performance and wider range of values for most the traits under study (seed cotton yield 60.89, 32-96 and 228.72). The high estimates of PCV and GCV were recorded for M4 generation for boll weight (20.82 and 20.29) and seed cotton yield (42.7 and 40.6) show simple irradiation helps to improve these traits whereas, $F_{4} M_{4}$ progenies recorded high PCV and GCV for seed index (11.2 and 10.29) indicating hybridization followed by irradiation has an additional advantage to improve this trait. The high heritability coupled with high genetic advance was noticed for seed cotton yield and yield components as well as fibre quality traits among progenies. When the assessment was made across the progenies for important traits to know how much percent has progressed to next generation the $F_{4} M_{4}$ contributed higher number of superior progenies for boll weight traits (10 progenies) and fibre length (7 progenies). The best performing progenies will be stabilizes over location and tested for their superiority with the existing variety.
\end{abstract}

Keywords Boll; Desi; Irradiation; Hybridization; Length; Progenies; Strength

\section{Introduction}

The cultivation of desi cotton is restricted to a few pockets because of low yield level and non-preference of modern textile mills due to their low fiber length and strength. But desi cultivars have immense potential for adaptation to any of the soil types and climatic conditions (i.e. highly adoptive to both abiotic and biotic stress). By improving seed cotton yield level and fiber quality, these cultivars can become good choice in present days were we are sensing high levels of fluctuation in climatic conditions.

Among desi cotton, cultivar, Jayadhar which belongs to $G$. herbaceum species released during 1950 and has been under commercial cultivation in Karnataka as a popular variety till date. There is need to improve Jayadhar with reference to its yielding ability and to enhance fiber quality mainly fiber length and strength.

Hence, any programme to improve productivity of desi cotton is through component traits like boll weight and boll number traits. Mohan and Sharma [1] experimentally demonstrated in pea, that additional variation could be generated in the $F_{2}$ by irradiation at $F_{1}$ stage. Kajjidoni et al. [2] have developed new improved variety in black gram by utilizing both gamma rays induced and hybridization. Hence, in present investigation, irradiation in combination with hybridization involving adapted parent and selected donors for boll weight, boll number and fibre quality traits to generate different progenies and to study extent of variability and isolation of superior progenies for seed cotton yield and fibre quality traits.

\section{Material and Method}

The experimental material was developed by using four donor parents viz., 9749 (boll weight), RDC-88 (fiber fineness), MDL-2582 (boll number) and DLSA-17 (fiber length and strength). The widely adapted cultivar Jayadhar was used as a female parent and donors were used as male parents to generate three single crosses (Jayadhar $\times$ MDL-2582), (Jayadhar $\times$ DLSA-17) and (Jayadhar $\times$ RDC-88), two hundred fifty seeds of each crosses along with Jayadhar (75 seeds) were subjected for gamma irradiation (50 Gy) at BARC Mumbai. Radiation helps both in increasing crossing over and inducing interchanges. In the present investigation, 110 progenies comprising of $F_{4} M_{4}$ (45), $M_{4}$ (13) and $F_{4}$ (52) generations were used as experimental material to study the variability for seed cotton yield and fiber quality traits and to make comparative assessment the role of irradiation in inducing variability for quantitative traits in desi cotton. These progenies were advanced in their previous generation based on seed cotton yield and fiber length traits considering Jayadhar as check. The data on the plant height, number of bolls per plant, boll weight, seed cotton yield per plant, ginning outturn, lint index, seed index, $2.5 \%$ span length, uniformity ratio, micronaire, maturity, tenacity and fiber elongation was recorded. Fiber quality was estimated by HVI instrument, at ARS, Heballi farm, UAS, Dharwad. The variability was estimated according to Burton and Devane [3] and were categorized as low, moderate and high a indicated by Sivasubramanian and Menon [4]. 


\section{Results and Discussion}

\section{Seed cotton yield and component traits}

Mean range and variance: When a comparison was made across three different progenies (Table 1 ), $\mathrm{F}_{4} \mathrm{M}_{4}$ progenies were superior based on overall mean for seed cotton yield (60.89) and number of bolls per plant (62.77) indicating advantage of irradiation of single cross over single cross progenies without irradiation.
Among the progenies of single cross irradiated $\left(\mathrm{F}_{4} \mathrm{M}_{4}\right)$ and Jayadhar irradiated $\left(\mathrm{M}_{4}\right)$ versus single cross $\left(\mathrm{F}_{4}\right)$ progenies, the F4M4 progenies recorded better mean values followed by $\mathrm{M}_{4}$ and $\mathrm{F}_{4}$ progenies for seed cotton yield, number of bolls per plant and plant height traits, except for boll weight for which $\mathrm{F}_{4}$ progenies recorded high mean boll weight (1.35) (Table 1).

\begin{tabular}{|c|c|c|c|c|c|c|c|}
\hline \multirow{2}{*}{ Progenies } & \multirow{2}{*}{$\mathbf{N}$} & \multicolumn{3}{|c|}{ Plant height (cm) } & \multicolumn{3}{|c|}{ Number of bolls/plant } \\
\hline & & Mean+SE & Range & Variance & Mean+SE & Range & Variance \\
\hline Single Cross Irradiated $\left(\mathrm{F}_{4} \mathrm{M}_{4}\right)$ & 45 & $161.2+0.71$ & $107.0-230$ & 926.9 & $62.77+0.44$ & $25-96$ & 365.58 \\
\hline Single Cross $\left(F_{4}\right)$ & 52 & $156.4+0.48$ & $92.5-200$ & 616.8 & $46.64+0.26$ & $30-86$ & 183.39 \\
\hline \multirow[t]{2}{*}{ Irradiated Jayadhar $\left(\mathrm{M}_{4}\right)$} & 13 & $159.3+1.80$ & $112.0-195$ & 726.3 & $50.60+1.09$ & $21-74$ & 265.26 \\
\hline & & \multicolumn{3}{|c|}{ Boll weight (g) } & \multicolumn{3}{|c|}{ Seed cotton yield/plant $(\mathbf{g})$} \\
\hline Progenies & & Mean+SE & Range & Variance & Mean+SE & Range & Variance \\
\hline Single Cross Irradiated $\left(\mathrm{F}_{4} \mathrm{M}_{4}\right)$ & 45 & $1.30+0.01$ & $0.81-1.60$ & 0.05 & $60.89+0.35$ & $32-96.0$ & 228.72 \\
\hline Single Cross $\left(F_{4}\right)$ & 52 & $1.35+0.01$ & $0.67-1.85$ & 0.07 & $46.25+0.21$ & $30-81.6$ & 122.52 \\
\hline Irradiated Jayadhar $\left(\mathrm{M}_{4}\right)$ & 13 & $1.20+0.02$ & $0.70-1.60$ & 0.06 & $59.85+1.71$ & $17-104.0$ & 654.21 \\
\hline
\end{tabular}

Table 1: Table for mean, range and variance values for seed cotton yield and its component traits in $\mathrm{F}_{4} \mathrm{M}_{4}, \mathrm{M}_{4}$, single cross $\mathrm{F}_{4}$ and double cross $\mathrm{F}_{3}$ progenies of desi cotton.

\section{Variability parameters}

The variability as measured by phenotypic coefficient of variability (PCV) and genotypic coefficient of variability (GCV) indicate the relative amount of variability present in progenies. Since variations are influenced by the magnitude of different traits, a measure of coefficient of variability is more useful in comparing between progenies. Among different progenies, the PCV estimate was higher than the GCV for seed cotton yield and all its component traits, for this we understand that the environment plays a major role on expression of these traits.

The high PCV and GCV estimates were recorded for boll weight trait in M4 progenies (20.82 and $20.29 \mathrm{~g}$ ) followed by $\mathrm{F}_{4}$ progenies (19.40 and 18.83). These results are in the tune of results reported by Basu [5] where they observed that $\mathrm{M}_{2}$ population had high coefficient of variation boll weight trait.

The highest variability estimates were recorded for seed cotton yield indicating the presence of significant amount of genetic variability for this character. Among the progenies $\mathrm{M}_{4}$ recorded highest estimates of PCV and GCV for seed cotton yield (42.74 and $40.66 \mathrm{~g}$ ) followed by remaining progenies.

The PCV and GCV estimates for number of bolls per plant across different progenies were of higher magnitude whereas $\mathrm{F}_{4} \mathrm{M}_{4}$ recorded as high as 32.19 and $25.81 \mathrm{~g}$ respectively. Similar trends of result were reported earlier by Mukhov [6] in G. hirsutum, he observed wide variation in number of bolls per plant in the $M_{2}$ population when exposed to gamma rays at 10,15 and $20 \mathrm{kr}$.

The heritability and genetic advance as percentage mean (GAM) estimates are the true indicators of genetic potentiality of the progenies which can be selected and tested for stability and stable performing progenies can be advanced and further used as a tool for selection. High heritability coupled with high GAM were recorded for all the categories of progenies for number of bolls per plant, boll weight, seed cotton yield and plant height traits. The priority should be given to those traits which have recorded higher estimates of heritability with GAM for realizing better gain through selection. Neelima and Potduckhe [7] evaluated cotton genotypes under rain fed condition and reported high heritability coupled with high genetic advance were obtained for yield and most of the yield components.

\section{Economic traits}

The ginning out turn (GOT) (which is an important trait next to seed cotton yield and it has significance in processing), lint index and seed index were considered as economic traits, most of progenies did not exhibited much differences for these traits based on their overall mean values (Table 2). However, the irradiated progenies, $\mathrm{M}_{4}$ (5.65) recorded highest seed index progeny mean compared to F4M4 (5.46) and $\mathrm{F}_{4}(5.28)$ progenies.

The variability estimates ranged from low to moderate among the progenies for GOT and seed index. Irradiated Jayadhar $\left(\mathrm{M}_{4}\right)$ progenies exhibited moderate PCV and GCV values for GOT, whereas $\mathrm{F}_{4} \mathrm{M}_{4}$ progenies for seed index (Table 3).

The high heritability coupled with moderate to high GAM were recorded for most of progenies for ginning out turn, seed index and lint index traits indicating selection can be resorted for the improvement of these traits in the future crop improvement programme (Table 3 ). 
Citation: Wadeyar B, Kajjidoni ST (2018) A Novel Approach to Boost the Seed Cotton Yield via Irradiation to Enhance the Boll Weight and Boll Number in Diploid Cotton. Mol Biol 7: 209. doi:10.4172/2168-9547.1000209

Page 3 of 5

\section{Fiber quality traits}

Improvement in fiber quality especially fiber length and fiber strength is essential in desi cotton since, desi cotton are poor in quality traits as mentioned above. The emphasis is given to improve fiber length and strength through hybridization followed by irradiation ways, the attempt was made to improve these fiber qualities in different categories of progenies.

\begin{tabular}{|c|c|c|c|c|c|c|c|c|c|c|}
\hline \multirow{2}{*}{ Progenies } & \multirow{2}{*}{$\mathbf{N}$} & \multicolumn{3}{|c|}{ Ginning out turn (\%) } & \multicolumn{3}{|c|}{ Seed index (g) } & \multicolumn{3}{|c|}{ Lint index (g) } \\
\hline & & Mean+SE & Range & Variance & Mean+SE & Range & Variance & Mean+SE & Range & Variance \\
\hline $\begin{array}{l}\text { Single Cross Irradiated } \\
\left(\mathrm{F}_{4} \mathrm{M}_{4}\right)\end{array}$ & 45 & $35.65+0.08$ & $27.0-42.0$ & 10.86 & $5.46+0.01$ & $3.2-6.5$ & 0.37 & $3.05+0.01$ & $1.7-4.2$ & 0.34 \\
\hline Single Cross $\left(F_{4}\right)$ & 52 & $35.08+0.06$ & $24.7-38.9$ & 8.19 & $5.28+0.01$ & $4.0-6.2$ & 0.24 & $2.94+0.01$ & $1.6-4.6$ & 0.33 \\
\hline $\begin{array}{l}\text { Irradiated Jayadhar } \\
\left(\mathrm{M}_{4}\right)\end{array}$ & 13 & $32.84+0.25$ & $25.0-39.8$ & 14.1 & $5.65+0.03$ & $4.6-6.3$ & 0.25 & $2.79+0.04$ & $1.9-4.1$ & 0.32 \\
\hline
\end{tabular}

Table 2: Table for mean, range and variance values for economic traits in $\mathrm{F}_{4} \mathrm{M}_{4}, \mathrm{M}_{4}$, single cross $\mathrm{F}_{4}$ and double cross $\mathrm{F}_{3}$ progenies of desi cotton.

\begin{tabular}{|c|c|c|c|c|c|c|c|c|c|c|c|c|c|c|c|c|}
\hline \multirow[b]{2}{*}{ Progenies } & \multirow[b]{2}{*}{$\mathbf{N}$} & \multicolumn{5}{|c|}{ Ginning out turn (\%) } & \multicolumn{5}{|c|}{ Seed index (g) } & \multicolumn{5}{|c|}{ Lint index (g) } \\
\hline & & $\begin{array}{l}\text { PCV } \\
(\%)\end{array}$ & $\begin{array}{l}\text { GCV } \\
(\%)\end{array}$ & $h^{2}(\%)$ & GA & $\begin{array}{c}\text { GAM } \\
(\%)\end{array}$ & $\begin{array}{l}\text { PCV } \\
(\%)\end{array}$ & $\begin{array}{l}\text { GCV } \\
(\%)\end{array}$ & $\mathbf{h}^{2}(\%)$ & GA & $\begin{array}{c}\text { GAM } \\
(\%)\end{array}$ & $\begin{array}{l}\text { PCV } \\
(\%)\end{array}$ & $\begin{array}{c}\text { GCV } \\
(\%)\end{array}$ & $\mathbf{h}^{2}(\%)$ & GA & $\begin{array}{l}\text { GAM } \\
(\%)\end{array}$ \\
\hline $\begin{array}{l}\text { Single Cross } \\
\text { Irradiated }\left(\mathrm{F}_{4} \mathrm{M}_{4}\right)\end{array}$ & 45 & 9.24 & 7.8 & 84.34 & 5.73 & 16.06 & 11.2 & 10.29 & 91.91 & 1.16 & 21.2 & 19.24 & 17.84 & 92.73 & 1.12 & 36.75 \\
\hline Single Cross $\left(F_{4}\right)$ & 52 & 8.16 & 6.41 & 78.56 & 4.63 & 13.2 & 9.34 & 8.15 & 87.28 & 0.89 & 16.79 & 19.54 & 18.05 & 92.39 & 1.09 & 37.18 \\
\hline $\begin{array}{l}\text { Irradiated Jayadhar } \\
\left(\mathrm{M}_{4}\right)\end{array}$ & 13 & 11.43 & 8.67 & 75.87 & 5.87 & 17.87 & 8.83 & 8.15 & 92.3 & 0.95 & 16.79 & 20.42 & 18.15 & 88.9 & 1.04 & 37.4 \\
\hline
\end{tabular}

Table 3: Genetic variability parameters for economic traits in $\mathrm{F}_{4} \mathrm{M}_{4}, \mathrm{M}_{4}$, single cross $\mathrm{F}_{4}$ and double cross $\mathrm{F}_{3}$ progenies of desi cotton

\begin{tabular}{|c|c|c|c|c|c|c|c|}
\hline \multirow{2}{*}{ Progenies } & \multirow{2}{*}{$\mathbf{N}$} & \multicolumn{3}{|c|}{$2.5 \%$ Span length $(\mathrm{mm})$} & \multicolumn{3}{|c|}{ Uniformity Ratio (\%) } \\
\hline & & Mean+SE & Range & Variance & Mean+SE & Range & Variance \\
\hline $\begin{array}{l}\text { Single } \\
\left(\mathrm{F}_{4} \mathrm{M}_{4}\right)\end{array} \quad$ Cross $\quad$ Irradiated & 45 & $21.18+0.03$ & $19-25$ & 1.76 & $53.48+0.04$ & $50-58.0$ & 2.97 \\
\hline Single Cross $\left(F_{4}\right)$ & 52 & $22.17+0.02$ & $20-26$ & 1.5 & $50.90+0.03$ & $44-53.6$ & 2.66 \\
\hline Irradiated Jayadhar $\left(\mathrm{M}_{4}\right)$ & 13 & $22.83+0.09$ & $21-26$ & 1.82 & $51.97+0.09$ & $49-54.0$ & 1.9 \\
\hline \multirow{2}{*}{ Progenies } & \multirow{2}{*}{$\mathbf{N}$} & \multicolumn{3}{|c|}{ Micronaire value ( $\mu \mathrm{g} / \mathrm{in})$} & \multicolumn{3}{|c|}{ Maturity Ratio (\%) } \\
\hline & & Mean+SE & Range & Variance & Mean + SE & Range & Variance \\
\hline $\begin{array}{l}\text { Single } \\
\left(F_{4} M_{4}\right)\end{array} \quad$ Cross $\quad$ Irradiated & 44 & $4.55+0.01$ & $2.9-5.7$ & 0.39 & $0.78+0.001$ & $0.64-0.88$ & 0.003 \\
\hline Single Cross $\left(\mathrm{F}_{4}\right)$ & 36 & $4.56+0.01$ & $3.2-5.6$ & 0.29 & $0.77+0.001$ & $0.65-0.90$ & 0.003 \\
\hline Irradiated Jayadhar $\left(\mathrm{M}_{4}\right)$ & 8 & $4.74+0.07$ & $3.8-5.9$ & 0.56 & $0.77+0.010$ & $0.6-0.86$ & 0.005 \\
\hline \multirow{2}{*}{ Progenies } & \multirow{2}{*}{$\mathbf{N}$} & \multicolumn{3}{|c|}{ Tenacity(g/t) } & \multicolumn{3}{|c|}{ Elongation (\%) } \\
\hline & & Mean+SE & Range & Variance & Mean + SE & Range & Variance \\
\hline $\begin{array}{l}\text { Single } \\
\left(\mathrm{F}_{4} \mathrm{M}_{4}\right)\end{array} \quad$ Cross $\quad$ Irradiated & 44 & $15.98+0.02$ & $14.0-19.0$ & 1.07 & $5.47+0.01$ & $4.60-6.3$ & 0.18 \\
\hline Single Cross $\left(F_{4}\right)$ & 36 & $16.39+0.03$ & $14.6-20.0$ & 0.98 & $5.22+0.01$ & $4.57-5.9$ & 0.1 \\
\hline Irradiated Jayadhar $\left(\mathrm{M}_{4}\right)$ & 8 & $16.26+0.09$ & $14.9-17.7$ & 0.86 & $5.11+0.02$ & $4.80-5.3$ & 0.03 \\
\hline
\end{tabular}

Table 4: Table for mean, range and variance values for fiber quality traits in $\mathrm{F}_{4} \mathrm{M}_{4}, \mathrm{M}_{4}$, single cross $\mathrm{F}_{4}$ and double cross $\mathrm{F} 3$ progenies of desi cotton 
Citation: Wadeyar B, Kajjidoni ST (2018) A Novel Approach to Boost the Seed Cotton Yield via Irradiation to Enhance the Boll Weight and Boll Number in Diploid Cotton. Mol Biol 7: 209. doi:10.4172/2168-9547.1000209

Page 4 of 5

All other traits like uniformity, maturity index and elongation recorded on par mean values in three different categories of progenies. The $\mathrm{M}_{4}$ (22.83) progenies recorded higher mean followed by $\mathrm{F}_{4}(22.17)$ and $\mathrm{F}_{4} \mathrm{M}_{4}$ (21.18) progenies for $2.5 \%$ span length trait (Table 4).

Another important fiber quality trait i.e., fiber strength or tenacity was studied in present investigation and the mean performance was on par among progenies of $\mathrm{M}_{4}, \mathrm{~F}_{4}$ and $\mathrm{F}_{4} \mathrm{M}_{4}$ generations.
The results reveal that majority of progenies exhibited low to moderate PCV and GCV values for all most all the fiber quality traits as mentioned in Table 5 indicating a narrow range of variability for these characters.

\begin{tabular}{|c|c|c|c|c|c|c|c|c|c|c|c|}
\hline \multirow{2}{*}{ Progenies } & \multirow{2}{*}{$\mathbf{N}$} & \multicolumn{5}{|c|}{$2.5 \%$ Span length $(\mathrm{mm})$} & \multicolumn{5}{|c|}{ Uniformity Ratio (\%) } \\
\hline & & PCV (\%) & GCV (\%) & $h^{2}(\%)$ & GA & GAM (\%) & PCV (\%) & GCV (\%) & $h^{2}(\%)$ & GA & GAM (\%) \\
\hline $\begin{array}{l}\text { Single Cross } \\
\text { Irradiated }\left(\mathrm{F}_{4} \mathrm{M}_{4}\right)\end{array}$ & 45 & 6.26 & 5.56 & 88.69 & 2.42 & 11.44 & 3.22 & 2.55 & 79.13 & 2.81 & 5.25 \\
\hline Single Cross $\left(F_{4}\right)$ & 52 & 5.53 & 4.79 & 86.59 & 2.19 & 9.86 & 3.2 & 2.44 & 76.3 & 2.56 & 5.03 \\
\hline $\begin{array}{l}\text { Irradiated Jayadhar } \\
\left(\mathrm{M}_{4}\right)\end{array}$ & 13 & 5.9 & 5.1 & 86.43 & 2.4 & 10.51 & 2.65 & 1.77 & 66.73 & 1.89 & 3.65 \\
\hline \multirow{2}{*}{ Progenies } & \multirow{2}{*}{$\mathbf{N}$} & \multicolumn{5}{|c|}{ Micronaire value ( $\mu \mathrm{g} / \mathrm{in})$} & \multicolumn{5}{|c|}{ Maturity Ratio (\%) } \\
\hline & & PCV (\%) & GCV (\%) & $h^{2}(\%)$ & GA & GAM (\%) & PCV (\%) & GCV (\%) & $h^{2}(\%)$ & GA & GAM (\%) \\
\hline $\begin{array}{l}\text { Single } \\
\text { Irradiated }\left(\mathrm{F}_{4} \mathrm{M}_{4}\right)\end{array}$ & 44 & 13.64 & 13.13 & 96.28 & 1.23 & 27.06 & 7 & 5.43 & 77.56 & 0.09 & 11.18 \\
\hline Single Cross $\left(F_{4}\right)$ & 36 & 11.75 & 11.16 & 94.97 & 1.05 & 22.99 & 6.83 & 5.17 & 75.64 & 0.08 & 10.64 \\
\hline $\begin{array}{l}\text { Irradiated Jayadhar } \\
\left(\mathrm{M}_{4}\right)\end{array}$ & 8 & 15.73 & 15.21 & 96.65 & 1.48 & 31.33 & 9.02 & 8.2 & 90.89 & 0.13 & 16.9 \\
\hline \multirow{2}{*}{ Progenies } & \multirow{2}{*}{$\mathbf{N}$} & \multicolumn{5}{|c|}{ Tenacity(g/t) } & \multicolumn{5}{|c|}{ Elongation (\%) } \\
\hline & & PCV (\%) & GCV (\%) & $\mathbf{h}^{2}(\%)$ & GA & GAM (\%) & PCV (\%) & GCV (\%) & $\mathbf{h}^{2}(\%)$ & GA & GAM (\%) \\
\hline $\begin{array}{l}\text { Single Cross } \\
\text { Irradiated }\left(\mathrm{F}_{4} \mathrm{M}_{4}\right)\end{array}$ & 44 & 6.46 & 4.79 & 74.05 & 1.58 & 9.86 & 7.84 & 7.66 & 97.74 & 0.86 & 15.79 \\
\hline Single Cross $\left(F_{4}\right)$ & 36 & 6.04 & 4.31 & 71.28 & 1.45 & 8.87 & 6.18 & 5.93 & 95.97 & 0.64 & 12.22 \\
\hline $\begin{array}{l}\text { Irradiated Jayadhar } \\
\left(\mathrm{M}_{4}\right)\end{array}$ & 8 & 5.72 & 5.3 & 92.61 & 1.77 & 10.91 & 3.41 & 2.79 & 81.72 & 0.29 & 5.74 \\
\hline
\end{tabular}

Table 5: Genetic variability parameters for fiber quality traits in $\mathrm{F}_{4} \mathrm{M}_{4}, \mathrm{M}_{4}$, single cross $\mathrm{F}_{4}$ and double cross $\mathrm{F}_{3}$ progenies of desi cotton.

Three different progenies exhibited high heritability estimates with variable GAM from low (uniformity ratio), moderate (2.5\% span length, maturity ratio, tenacity and elongation traits) to high (micronaire trait) GAM values. A high genetic gain along with high heritability would suggest suitable conditions for making effective selection.

\section{Frequency of superior progenies}

The assessment of progenies based on their means and variability, alone will not indicate the worth of progenies for identification of superior progeny. In present study an attempt was made to identify potential progenies for seed cotton yield, its component traits and similarly for fiber quality traits based on mean plus one standard deviation criteria.

As many as 16 progenies were superior for seed cotton yield as against 21 for boll weight and 18 for number of bolls per plant. Among different progenies, F4 contributed higher number of superior progenies for seed cotton yield, bolls per plant and boll weight. The similar approach of work was made earlier by Talwar and Kajjidoni [8] where they observed higher number of superior progenies for number of bolls per plant, seed cotton yield per plant and tenacity. It is interesting to note that out of 100 , there were only four progenies which were common for three traits (Table 6).

Similarly for fiber quality traits, as many as 70 superior progenies were scored for micronaire followed by fiber length (17) and fiber strength (10) traits when a comparison was made between different progenies were $\mathrm{F}_{4} \mathrm{M}_{4}$ followed by $\mathrm{F}_{4}$ exhibited more number of superior progenies for fiber length and micronaire value, whereas for tenacity $\mathrm{F}_{4} \mathrm{M}_{4}$ and $\mathrm{F}_{4}$ progenies were on par with four progenies each suggesting that these progenies can be used as base material for further improvement of fiber strength. Out of 100 progeny lines three progenies found to be common for fiber length, fiber strength and micronaire values (Table 7). 
Citation: Wadeyar B, Kajjidoni ST (2018) A Novel Approach to Boost the Seed Cotton Yield via Irradiation to Enhance the Boll Weight and Boll Number in Diploid Cotton. Mol Biol 7: 209. doi:10.4172/2168-9547.1000209

Page 5 of 5

\begin{tabular}{|l|c|c|c|c|c|}
\hline Progenies & $\mathbf{N}$ & $\begin{array}{c}\text { Number of bolls/ } \\
\text { plant }\end{array}$ & Boll weight (g) & $\begin{array}{c}\text { Seed cotton yield/ } \\
\text { plant }(\mathbf{g})\end{array}$ & $\begin{array}{c}\text { Common progenies across the seed cotton } \\
\text { yield and component traits }\end{array}$ \\
\hline $\begin{array}{l}\text { Single Cross Irradiated } \\
\left(\mathrm{F}_{4} \mathrm{M}_{4}\right)\end{array}$ & 45 & $8(17.8)$ & $10(22.2)$ & $6(13.3)$ & 2 \\
\hline Single Cross $\left(\mathrm{F}_{4}\right)$ & 52 & $9(17.3)$ & $8(15.4)$ & $9(17.3)$ & 2 \\
\hline Irradiated Jayadhar $\left(\mathrm{M}_{4}\right)$ & 13 & $1(7.7)$ & $3(23.1)$ & $1(7.7)$ & 0 \\
\hline Total & & & & & 4 \\
\hline
\end{tabular}

Table 6: Frequency of superior progenies for seed cotton yield and its component traits in desi cotton

\begin{tabular}{|l|c|c|c|c|c|c|}
\hline Progenies & $\mathbf{N}$ & $\begin{array}{c}\mathbf{2 . 5 \%} \text { Span length } \\
(\mathbf{m m})\end{array}$ & $\mathbf{N}$ & Tenacity(g/t) & $\begin{array}{c}\text { Micronaire value } \\
(\boldsymbol{\mu g} / \mathbf{i n})\end{array}$ & $\begin{array}{c}\text { Common progenies across the fiber } \\
\text { quality traits }\end{array}$ \\
\hline $\begin{array}{l}\text { Single Cross Irradiated } \\
\left(\mathrm{F}_{4} \mathrm{M}_{4}\right)\end{array}$ & 45 & $7(15.5)$ & 44 & $4(9.1)$ & $37(84.1)$ & 2 \\
\hline Single Cross $\left(\mathrm{F}_{4}\right)$ & 52 & $6(11.5)$ & 36 & $4(11.1)$ & $31(86.1)$ & 1 \\
\hline Irradiated Jayadhar $\left(\mathrm{M}_{4}\right)$ & 13 & $4(30.8)$ & 8 & $2(25.0)$ & $2(25.0)$ & 0 \\
\hline Total & & & & & 3 \\
\hline
\end{tabular}

Table 7: Frequency of superior progenies for fiber quality traits in desi cotton.

\section{Conclusion}

When a comparison between number of superior common progenies for seed cotton yield and fiber quality and their component traits, it is interesting to note that, $\mathrm{F}_{4} \mathrm{M}_{4}$ and $\mathrm{F}_{4}$ produced common number of superior progenies for seed cotton yield and $\mathrm{F}_{4} \mathrm{M}_{4}$ for fiber quality traits. These results amply support role of $\mathrm{F}_{4} \mathrm{M}_{4}$ in producing better progenies for both seed cotton yield and fiber quality traits. Hence there is greater advantage in irradiation of $\mathrm{F}_{1 \mathrm{~s}}$ to enhance variability and isolation of superior progenies, as compared to irradiation of parental lines. This evidenced by performance of progenies of irradiated Jayadhar by way of nil contribution to common superior progenies for both seed cotton yield and fiber quality traits (Table 7).

\section{References}

1. Mohan D, Sharma B (1995) Increasing induced polygenic variability in pea. In: Genetic Research and Education : Current Trends and the Next Fifty Years (Eds.), Indian Society of Genetics and Plant Breeding, New Delhi. pp: 1333-1342.
2. Kajjidoni ST, Roopalakshmi K, Immadi S, Nagaral R, Nagaral I (2008) An innovative way of developing an improved variety utilizing both gamma rays induced and recombinational variability in blackgram (Vigna mungo (L.) Hepper). FAO/IAEA Intl Symp on Induced Mutations in Plants 12-15 August, 2008, Vienna, Austria IAEA-CN-167-064 p 142.

3. Burton GW, Devane EM (1953). Estimating heritability in fall fescue (Festecd cirunclindcede) from replicated clonal material. Agron J 45: 478-481.

4. Sivasubramanian S, Menon M (1973) Heterosis and inbreeding depression in rice. Madras Agric J 60: 1139.

5. Basu AK (1982) Note on induced variability in upland cotton by one and two cycles for gamma irradiation. Indian J Agric Sci 52: 402-403.

6. Mukhov V (1986) The possibilities of improving cotton yield through radiation mutagenesis Rasteniev dni-Nauki 23: 21-24.

7. Neelima GD, Potduckhe NP (2002) Studies on variability and correlations in upland cotton for yield and its components. J Indian Soc Cotton Improv 27: 148-152.

8. Talwar AM, Kajjidoni ST (2010) Frequency of superior segregants as influenced by hybridization (F2) and hybridization followed by irradiation (F2M2) using selected parents for important component traits in desi cotton. Electronic J Plant Breed 1: 675-679. 